\title{
Playground of Violence: Mennonites and Makhnovites in the Time of War and Revolution
}

\author{
Mikhail Akulov \\ The Kazakh-British Technical University, Almaty, Kazakhstan
}

\begin{abstract}
Focusing on the relationship between the German Mennonite colonists and the self-professed followers of Nestor Makhno, this paper attempts to present a view of the Revolution in which participants are seen primarily through the framework of competition, rather than through binary narrative structures of victims vs. perpetrators, bourgeoisie vs. proletariat, revolutionaries vs. counterrevolutionaries, etc.. Always with an eye at a real or an imagined opponent, the Mennonites and the avowed adherents of the fabled bat'ko ended up profoundly influencing one another, conditioning one's moves and limiting one's latitude as does the omnipresent other vis-a-vis the unfolding self. In that light, violence, which both sides had on their record, functioned to cement such ongoing dialects, carrying the protagonists of these turbulent times well beyond their original intentions.
\end{abstract}

Keywords: Russian Civil War, violence, Makhno, Mennonites, revolution

\section{Introduction}

The Russian Revolution, a subject relegated from the top priorities of the scholarly scrutiny in the late 1990s and early 2000s, is now making a comeback. The multiple jubilees are certainly working in its favor. Thus, pouncing upon the opportunity proffered last year by the centennial anniversary of the Great War, historians put themselves to the task of narrating the event, compelling bookstores to tone down their somewhat lurid fascination for the violence of the Second World War and allocate few extra bookshelves to the recorded dramas of the earlier catastrophe; Revolution, of course, remains among its paramount chapters (Borodziej \& Górny, 2014; Leonhard, 2014; Astashov, 2014; Sanborn, 2014). ${ }^{1}$ An equally copious and even more direct outpouring could be expected within the span of the next two years as the Revolution nears its own symbolic date. For better or for worse, global events too-from the occupy movement with its mix of anti-globalist and anti-capitalist discourse, through the Arab Spring all the way to Ukraine's present tribulations-feed into the growing public interest in the revolts and revolutions (bygone, but not accomplished) ${ }^{2}$ and keep in that manner the selfsame historians busy pondering over and writing about the planetary quaking of 1917.

The incentive to penser la Revolution russe (to borrow and amend the title of Francois Furet's book) might very well stem from considerations of all but academic nature. Yet, this does not make it any less of a windfall, a heaven-sent (or market-sent) opportunity. Much is done to emancipate the Revolution from the clutches of the

Mikhail Akulov, Ph.D., History Department, The Kazakh-British Technical University.

1 WWII, on the contrary, does not seem to extract too great a profit from the outstanding anniversary of its end; it does not need to, selling equally well in fat and lean years as it does.

${ }^{2}$ A blog created under the auspices of a seminar I took at Harvard in 2011 illustrates that point well. Retrieved from http://historicizingrevolutions.blogspot.com/ 
Marxist or the totalitarian school interpretations (which, surprisingly enough, agree in their basic tenets); moribund is the assumption of the Bolshevik (or any other party's) monopolistic claim to agency in a country otherwise marked by elemental and erratic commotion. Hopelessly parochial appear to us accounts from the traditional perspectives of politics, society and economics; instead, words, symbols, histrionic gestures and sundry revolutionary repertoires ${ }^{3}$ constitute new contested grounds between the historians striving to construe the meaning of the Revolution as its participants saw it.

Partially as a result of a timely intervention from the field of anthropology and cultural studies, the revolutionary violence too cast off its epiphenomenal status, revealing itself to be infinitely more than a mere congeries of actions tailored to wreck damage upon those of different persuasion. In his recent work on peasant militancy in Ukraine between the Revolution of 1905 and the collectivization, Felix Schnell paints the Hobbesian landscape of bellum omnium contra omnes, where one had little left beyond the peremptory choice of being either a victim or a perpetrator (Schnell, 2012, p. 9). Under such circumstances, he further argues, violence transmogrified into an indispensable existential element "through which community, hierarchy and identity were produced and reproduced" (Schnell, 2012, p. 316). Nestor Makhno and other, lesser atamans, therefore, were resorting to brutality in order to inform the revolutionary times (conscious as they were of them in the highest degree) with content worthy of the name, the fact giving rise to accusations of wantonness and arbitrariness leveled against the former by the survivors and unsympathetic posterity alike.

While recapitulating the centrality of violence for the praxis of revolution, this paper tries to depart from habit of relying too much on the customary dichotomy of victims against the perpetrators. ${ }^{4}$ It is based, instead, on the vision of the Revolution as an undertaking of wiping off the old structures and opening up new spaces wherein all actors willy-nilly came to define themselves. In that respect, their professed positions notwithstanding, no actor, willing or reluctant though he may be, was truly "counterrevolutionary", the Counterrevolution encompassing a set of projects for the re-organization of Russia or of its parts made possible only by the Revolution. In the exchange between the Ukrainian Mennonites and the Makhnovites-ordinarily placed either under the rubric of the "martyrs and villains" (the Mennonite perspective) or the "bourgeoisie and proletariat" (in the rural guise, as it behooves the Makhnovite views) - both participants entered carrying their own visions of a post-Revolution order with elements often at full variance with their previous lived experiences. As the state arbiter saw itself stripped of all effective control, and with political stakes dramatically heightened, the aforementioned actors felt less inhibited trying out solutions not only risky but at times outright fantastic, such reciprocal alacrity to radicalism becoming soon the quintessence of the revolutionary climate. Operating always with an eye at a real or an imagined opponent, the Mennonites and the avowed adherents of the fabled bat'ko ended up profoundly influencing one another, conditioning one's moves and limiting one's latitude as does the omnipresent other vis-a-vis the unfolding self. Violence, which both sides had on their record (albeit not in the commensurate degree), functioned to cement such ongoing dialects, carrying the protagonists of these turbulent times well beyond their original intentions.

\section{Mennonites and the Revolution}

Invited in the late 18th century to settle the newly-acquired territories in the southern Ukraine, by 1900 the

\footnotetext{
3 A phrase employed by Professor Terry Martin in the aforementioned seminar.

${ }^{4}$ In this epistemological respect, it finds itself in full accord with a promising master's thesis of Sean D. Patterson on the makhnovites and the Mennonites (Patterson, 2013).
} 
Mennonites constituted a solid cultural-religious community of more than 65 thousand individuals concentrated in the colonies of the Yekaterinoslav, Tavria, Kherson and Samara provinces (Obshchii svod po imperii rezul'tatov razrabotki, 1905, pp. 250, 254; Entsiklopedicheskii Slovar' Brokgauza i Efrona, 1896, pp. 94-96). ${ }^{5}$ More than a century spent under the scepter of a Russian tsar did little to dilute their sense of corporate identity; if anything, the Mennonites' adherence to the religious precepts (pacifism, refusal to take oaths or to participate in litigations, biblical literalism, etc.) became only more tenacious, as the bungled effort at introducing military conscription (resulting only in the exodus of the Mennonites) appear to illustrate. At the same time, that self-conscious distancing and the internal consolidation did not preclude the Mennonites from being conscientious imperial subjects never at a loss as for the reasons they were granted land and privileges from the state hardly known for its liberal practices. Excelling in turning the region into a paragon of agricultural efficiency, they received unstinted praises in the official discourse as "assiduous, order loving, morally upright, humane and sober". These characteristics were carefully chosen to accentuate the foil with the surrounding populace, yet, with their impact upon the "Russian peasants" judged "of salutary nature" — as the author of an encyclopedia entry averred — one could expect of the latter to start living up to the example set by the colonists (Entsiklopedicheskii Slovar' Brokgauza i Efrona, 1896, p. 96).

Whether the impact of the Mennonites upon the Ukrainian countryside was salutary or not is hard to say, yet the difference between them was real enough. In the region of an average peasant landholding of about 6.3 desiatin, the colonist farm could easily boast 10 times as much (Patterson, 2013, p. 40). The Mennonites' practice of bequeathing a farm property undivided into the hands of a single male descendants favored the establishment of small families, which must have appeared particularly conspicuous in provinces with the highest fertility and lowest mortality rates in the European portion of the Empire (Rubakin, 1912, p. 44). Countryside denizens as their Ukrainian neighbors, the colonists were incomparably more urbane - at least as far as the literacy figures were concerned. Among the 25,000 Mennonites residing in the Tavria province, for instance, more than 18,000 (over 70\%) were considered literate, most of them, in fact, in both Russian and German languages; in contrast, less than one out of five Ukrainian peasants possessed a modicum of reading and writing skills (Pervaia vseobshchaia perepis' naseleniia Rossiiskoi Imperii, 1897, 1904, pp. 98, 100, 127). Moreover, gender was no factor of import in the spread of literacy within the Mennonite community, since boys and girls were being admitted to schools (by and large three-year zemstvo schools) on an equal basis and in equal measure. For the Ukrainian population, the male-female divide run very deep, the aforementioned $20 \%$ rate dropping to a mere $6 \%$ when applied to the women population.

The generally symbiotic relationship between the Tsarist state and the Mennonites came to an end with the outbreak of the Great War. Despite the efforts of the latter to dissociate themselves from the compromising German provenance by planting putative Dutch roots in its stead-a demarche referred to as the Hollanderei (Patterson, 2013, pp. 86-87) ${ }^{6}$ the anti-German propaganda campaign and the war-driven ethnicization of the social relations turned them overnight into the bearers of an alien culture as well as subjects of ambiguous

\footnotetext{
${ }^{5}$ Samara province was being settled by the Mennonites between 1854 and 1874, who formed there 16 colonies in Novouzensk and Samara uezds of the said province.

${ }^{6}$ I remember meeting a Mennonite woman three years ago, then an employee of a Viennese optics store, who kept on describing herself as a Hollender and her native tongue - in opposition to the Hochsdeutsch in which she was perfectly fluent-as a derivate of Dutch.
} 
loyalty. ${ }^{7}$ The lumping together of all the German-language groups, indwelling hitherto the non-overlapping niches in the complex imperial habitat, resulted in the emergence of a myth of "German exploitation" (zasil'e) and the Mennonites, with their long-standing services rendered to the colonizing enterprise of the regime, fit the description of a national exploiter all too well (Fediuk, 2010, pp. 78-96). In such a twist of fate then, the community who professed to be "a patriotic, culturally useful... member in the large family of Russia," trusting in "God and the tsar" (Patterson, 2003, p. 81) evolved, in words of a modern scholar, into a "parasite, successful in attaining prosperous position thanks to the state privileges, a social group, contributing nothing to the Russian society and capable of betraying state interests" (Venger, 2011). ${ }^{8}$

The anti-German propaganda inevitably made the pent-up social resentment of the Ukrainian peasantry against the colonists - seen as land proprietors or as tightfisted employers of farm hands - appear at least semi-legitimate. With the state power eroding towards the close of the war, the originally plaintive tone turned more and more peremptory, symptomizing what many an observer (including the Mennonite ones) described as the "awakening" of the village from the slumbers of passivity and subservience (Neufeld, 1921, p. 5). ${ }^{9}$ As in the case of large noble landowners, the situation with the Mennonite land holdings exacted immediate redress, if necessary by means contrary to the conceptions of conventional legality. The convergence of peasant social aspirations with the ideals of unqualified justice set the prelude for the Revolution, converting en route the Mennonite farmer into "the German kulak" of the future Makhnovite chronicles.

With the imperial state gone and the army crumbling into the myriads of home-bound, arm-wielding packs of ex-soldiers, the Mennonites were left to face the agitated populace on their own. "In the central colony (of the Berdiansk uezd-M. A.) Halbstadt, wrote a Mennonite pastor W. L. Jack to the German embassy in Stockholm in March 1918, where to many of the once affluent landowners fled after seeing their estates utterly plundered and destroyed, the [Black See] sailors made their extortionary demands known or, as they call them, their contributions. Five of the most distinguished landowners are murdered, others waste away in a prison for not being able to pay the exacted sums...". ${ }^{10}$ Leaving aside the question of frequency with which such excesses transpired, most of the colonists took for granted the aggressive indisposition of their orthodox neighbors, who in their mind finally got the opportune moment to lay hands on the coveted property. That fear of peasants, undifferentiated and overwhelming in their mass, gave the Revolution its most characteristic poignancy, conditioning the colonists' phenomenological experience of the event. Under the duress of times, countenancing threats real or imagined, steeped in the alacritous radicalism of the moment, the Mennonites opted to pursue plans of their own, unprecedented and radical at once.

The story of the Mennonite self-defense, or Selbstschutz, is relatively well chronicled to be dwelt here at length. What needs to be stressed here, however, is not only how drastic a departure it was from the key tenets of pacifism and antimilitarism, but that this extemporaneous response to the unforeseen challenges was

\footnotetext{
7 On the general phenomenon of the ethnicization in the western borderlands of the Russian Empire (Borodziej \& Górny, 2014, pp. 225-233); Felix Schnell provides a good discussion about the extension of the novel principles into the spaces of the Russian Civil War (Schnell, 2012, pp. 223-238).

${ }^{8}$ One could further ask how much the anti-German war propaganda played into hands of the regime's opponents.

9 the growth of self-confidence must have surely been instigated by the war-time prosperity of the peasants against the notable deterioration of the urban living standards. For many peasants, after all, the Revolution was the chance to turn the tables against the execrable city and its mode of dominance.

${ }^{10}$ Politisches Archiv des Auswärtigen Amtes (PAAA), Berlin, R 14366, W. L. Jack an die Kgl. Schwedische Gesandtschaft, Abt. B, Kologriw, 9. März 1918
} 
beginning to show every sign of institutional permanence. ${ }^{11}$ Established with an extensive technical and organizational support from the occupying Austro-German authorities, ${ }^{12}$ the Mennonite Selbstschutz by all accounts did more than merely defend colonists' property from the untoward peasant visitors. Its participation in punitive undertakings alongside the regular troops and Hetman's varta is documented not only in the Makhnovite literature, but in the contemporary official communiques (Makhno, 1992; Belash, A., \& Belash, V., 1993, p. 317; Danilov et al., 2006, pp. 51-52). Having emerged from the year 1918 relatively unmolested, the Selbstschutz began developing cooperative scenarios with the whites in lieu of the Germans primed to withdraw. Few months later, with the summer battles between Denikin's Volunteers and the Reds in full swing, white officers were dispatched to the colonies to see if the Selbstschutzler could be organized along the regular army lines. The results proved disappointing, although not unsubstantial—some 10 or 11 companies were put together to the north of Melitopol in addition to a small regiment in the environs of Odessa. ${ }^{13}$

The whites themselves tended to explain the failure to mobilize more by the colonists' fear of the Makhnovite or Bolshevik reprisals. ${ }^{14}$ No doubt, they must have loomed large in the collective psyche of the Mennonites (and that of other German colonists), yet, the uncertainty of the grand strategic outcome combined with the near-certainty of the Bolshevik shooting squads riding into colonies on coattails of the retreating whites points in a different direction - namely, to the nature of the Selsbstschutz itself. Epitomizing the so-called voluntary principle (dobrovolcheskoe nachalo), the Mennonite self-defense (as, for that matter, all other countless peasant militias) stressed the growing sense of autonomy of a small commune vis-a-vis the absentee Center and the greater Imperial commonwealth, an adaptation and a habituation to the disintegrating effects of a civil strife. The Selbstschutzler, paradoxically, went to enlist en masse into the ranks of the Volunteer army when its fortunes were at their lowest, yet, with arms and uniforms securely in their hands, ${ }^{15}$ they made off back into their native villages as if challenging the right of the restorationist projects to freely dispose of the military materiel. In other words, the same factors, which made short work of the cooperation between the Bolsheviks and the plethora of the Ukrainian atamans (from Makhno and Grigoriev downward), were at play here. As a successful concretization of the autonomist opportunities proffered by times, Selbstschutz, after all, was a specifically Mennonite tribute to the spirit of revolutionary warlordism.

Another project cut for the paramount indeterminacy ushered by the Revolution is connected with the name of Immanuel Winkler (1886-1932), a pastor of a German Bessarabian extraction. Making up in creativity where his ideas lacked in feasibility, he proposed to establish a state for the colonists along the Black Sea littoral (Crimea and the surrounding territories), which, bound to Germany by sinews of alliance, would, in his words, "salvage the results of a one-hundred year cultural work (Kultur-Arbeit) carried out by [the Colonists] and their ancestors". ${ }^{16}$ His arguments did not fall on deaf ears, causing some stir among the Olympians of the German wartime elite. "The colonists treat the incorporation (Angliederung) of the areas settled by them in

\footnotetext{
${ }^{11}$ Referring to the general situation in the Ukrainian countryside, Felix Schnell describes this process as the transition from improvised resistance groups to permanent peasant militias, which, in their turn, had given rise to the Ukrainian atamans (Schnell, 2012, p. 238).

12 PAAA R 14366, Ludendorff an Mackensen, Gr. Hauptquartier, den 17. April 1918; R 14370 Der K. Legationssekretar an Ausw. Amt., Gr. H. Qu., den 8. Mai

${ }^{13}$ GARF f. 5956 o. 1. d. 370 "Dobrovolcheskie formirovaniia nemtsev-kolonistov Sev. Tavrii (period ianvar'-fevral 1919), p. 3; GARF f. 5956 o. 1 d. 391 Materialy b. Nachal'nika shtaba Voisk Novorossiiskoi oblast gen.-maiora Chernavina (Sobytia v pravoberezhnoi Ukraine i raione Odessy vo 2 polovinu 1919 g. i po ostavleniiu Odessy), 11. 6, 7

${ }^{14}$ GARF f. 5956 o. 1 d. 3911.8

15 GARF f. 5956 o. 1 d. 701 7; Zapiski Chernavina V.V. o "nemtsakh-kolonistakh Chernomorskogo kraia" (1919-1920).

16 PAAA 14366 Der Botschafter a.D. an Auswärtiges Amt, Kiew, den 13. April 1918.
} 
Ukraine and Crimea to the German Reich... as a done deal", wrote on May 28 Alfons Mumm, the head of the civic mission in the occupied Ukraine and possibly, along with the Field Marshal Eichhorn and General Groener, the most influential official there. ${ }^{17}$ Mumm himself was rather skeptical about the prospects of a creole polity on a sea coast, rightly pointing at the message that Germany's overt support might communicate to the apologists of Ukraine's sovereignty. Ludendorff, the all-mighty Quartermaster General and Germany's virtual dictator, felt otherwise, given as he was towards the war's close to desperate political gambles. Recognizing the inexpediency of proceeding ahead with the establishment of a German colony, he, nevertheless, wanted to see Crimea and Tavria form an autonomy within Ukraine, standing to Ukraine, "as does Bavaria to Prussia". The area in question would become then a home for all the Germans remaining in the "South Russia" as well as a major base of German navy power. ${ }^{18}$

To be sure, nothing came out of those plans, but, as one could see, it was not for the lack of trying on Winkler's part, or because of the flagging political will among the higher-ups. The Central powers were racing against time and as their military efforts took a nosedive, the projects receiving their explicit support had to fold up as well. Somewhat ironically, Germany's defeat prolonged the existence of that great Eurasian realm of experimentation east of Vistula (or Oder? or Rhine?), which, it must be recalled, was the very precondition for the Selbstschutz and the colonists' mental detours in the direction of a home state. The Revolution lured everyone with stake in the future to make a bid, the Mennonites being no exception. The problem was - at least from the Mennonite perspective - that they were not the only players involved.

\section{Makhnovite Response}

The Makhnovite "Army" as an expression of a Ukrainian peasant militancy was another such player. Again, this is not the place to discuss a history of the movement, being a subject of multiple serious or semiserious (or sometimes outright preposterous) investigations ever since the few surviving Makhnovites laid down their rusty sabers in order to get a better hold of a pen. There is an ongoing discussion as to whether Makhno's followers were "genuinely" anarchist or not, with the opponents of the thesis stressing the lack of a coherent and bounding program and the supporters as a rule appealing to the word and letter of the great Makhnovite gospels (Makhno-Arshinov-Voline-Belash). It remains undeniable, however, that in their dashing raids and harrowing retreats, the Makhnovite troops were destroying signs and symbols of distant authority, from city archives, notarial records to police stations and municipal prisons. This behavior, typical of large-scale agrarian revolts, betokens less its anti-authoritarian (vlastnicheskii, a Makhnovite neologism) character, as the "anti-rationalized" bias, a rejection of a system of rule displaying increasing impersonal and bureaucratic tendencies. The idea of power, or its practice, was never too far from Makhno's mind and his deeds, yet, it was the power, originating in what I once dubbed the politics of proximity, one in which the rapports between the governing and the governed (a rather blasphemous expression) streamlined in a reputedly unmediated fashion, without succumbing to the dampening effects of stolid state interpreters (Akulov, 2012). ${ }^{19}$ Makhnovia, as the swaths of land controlled by Makhno's men was sarcastically called (Danilov et al., 2006, pp. 200-202), gravitated towards the ideal of a muzhitskoe tsarstvo, the muzhik kingdom of lore and yore,

\footnotetext{
17 PAAA 14372 Der Botschafter a. D. an Auswärtiges Amt, Kiew, den 28. Mai 1918

18 PAAA 14373 Ludendorffs Besprechugn mit dem Staatssekretär a. D. von Lindequist am 31.5

19 Whether Makhno was physically present and visible to his followers became less important with time, for his proven charisma began to work for him as an acceptable stand-in, infusing claims of his lieutenants with its men-propelling capacity.
} 
without knout, noose and tax collector, but with a just bat'ko in the center.

That bat'ko may have had personal reasons for disliking German colonists- he is said to have worked on a wealthy colonist's estate as a boy (Arshinov, 1995, p. 51); the personal grudge may have found its way into the larger class-based Weltanschauung, facilitating the conversion of the Mennonites into the rural surrogate of bourgeoisie, a point enjoying certain currency today. Then again, he could have chosen other groups in the pursuit of the expiatory class war-local Jewish residents, for example, who were culturally distinct and appeared better-off to raise a red flag among Makhno's less discriminatory adherents. To his credit, however, bat'ko attitude towards the pogromists was genuinely and consistently inimical as he was known to have hanged the culprits whenever he could lay his hands on them (which did not happen too frequently). ${ }^{20}$

In the Makhnovite scheme alluded to above, the Mennonites were the competitors, not the victims. Their participation in punitive operations, creation of their own militia (controversial and divisive as this step was), the unconcealed enthusiasm at the sight of the German troops provided enough material to show the Mennonites' active involvement in the revolutionary power-play- on the side of the "counterrevolution". Just as the fear of an ominous countryside conditioned decisions of the colonists, so did the Makhnovite suspicions fed into their treatment of the Mennonites, and by extension, into the form their revolutionary politics had assumed. With "counterrevolution" retroactively divulging the "bad faith" of the colonists, the Makhnovites experienced no compunction in abusing their Mennonite neighbors even when encountering no sign of hostility from them. Thus, when Binetsky, a white officer brought by a fluke into the Makhnovite rank-and-file, asked his young companion about the reasons for mistreating a German colonist, "a polite and friendly old man", he received a reply: "Because they are swines, not people... you don't know them: it's only now that they grew quiet, but early, before the war-they wouldn't as much as talk with a peasant" (Makhno, 2006, p. 781). That same Binetsky, not a Makhnovite sympathizer, felt compelled to add elsewhere that in the summer months of 1918, "the German colonists and the landowners did not spend much time deliberating with the muzhik, charging him twice and even three times for their plundered and damaged property". ${ }^{21}$

The Makhnovites did not intend to destroy the colonists, but rather to "tame" them. Bat'ko admits as much. Referring to the Mennonite landholders, he wrote: "These owners could have been destroyed together with their manors. But their lives was not what the insurgency was after; rather, it aspired to exert pressure upon their psyche, attain the physical victory over them, the necessity of which was dictated by the moment" (Makhno, 2006). What they wanted in the end was to render the colonists harmless, i.e. divest them of active agency in the revolutionary drama and make them into the passive recipients of the Makhnovite grace. Plurality of visions is brooked or even encouraged in the quiet times, their scope carefully demarcated by law and custom, but in the Revolution, with everything up in the air, the Hegelian "World-Spirit" must act with an iron single-mindedness or at least so it must have appeared (if not in such terms) to all the major participants of the Civil War, revolutionary and counterrevolutionary alike.

What ensued, however, was the reign of semi-indiscriminate terror. Extensive is the dolorous panoply of the Makhnovite murder scenes: Eichenfeld, where more than 80 colonists were shot, Orlovo with 44 victims, Hochfeld with 19, etc. (Venger, 2011, p. 10). ${ }^{22}$ To those executed must be added the uncounted victims of rape,

\footnotetext{
${ }^{20}$ Nataliia Venger, a contemporary Mennonite scholar, considers anti-German and anti-Jewish pogroms "phenomena of the same order", but I think she misses the point (Venger, 2011, p. 13).

21 GARF r-6562 o 1 d 2 Manuscript of Binetsky "Zapiski o 1917-1918” Kiev, 1. 9

22 According to modern research, in 1919 alone 827 Mennonites fell victim to terror (Patterson, 2013, p. 56).
} 
theft, physical and moral abuse. Typhus brought into colonies by the infected Makhnovite armies further decimated the villagers, cementing the Mennonite impression of facing the Satan himself and giving rise to the narrative of martyrdom (Patterson, 2013, p. 25).

Ultimately, not only did the violence prevail over the stock of moderation that the Makhnovites still possessed, but it also became the indispensable element if not the centerpiece of the revolutionary practice. Felix Schnell writes, in fact, of violence as providing the litmus test of Makhno's leadership skills, of his revolutionary mission, of his charisma and his presence tout court (Schnell, 2012, pp. 325-331). Makhno killed, therefore he was. That principle proved among the causes of his undoing. Beginning as a peasant initiative at self-organization and progressing through the many struggles to a movement encompassing tens if not hundreds of thousands of individuals, Makhnovshchina found little to offer beyond the struggle itself and the rough legend of its leader. The Bolsheviks, whose own terrorist record dwarfs by a wide margin any of their opponents, proved infinitely superior to the ineluctable bat'ko in that they were able to give peasants peace. They simply had to wait until the countryside grows fatigued with Makhno's exploits and then, upon reducing Makhno's army to a ring of wandering bandits, offer the peasantry what it was pining after.

\section{Conclusion}

Far from incriminating one side or exculpating the other, this paper attempted to present a different paradigm for framing the Revolution, that of a playground with free tickets for all. The players step into the magic circle with the internalized memories from the past and the radical dreams for the future. Seeing the other act, they respond accordingly, creating certain patterns which they are bound to reproduce. The Mennonites and the Makhnovites, coming from the opposite points of entry, found themselves competing over the same turf. They were locked in a struggle from which none emerged as a victor, but none was defeated either. Their story is riddled with exertion, disappointments, dramas and unspeakable tragedies, but it also remains a story with a room for reconciliation - if only for the sake of those long gone and if only on a level of a mere narrative.

\section{References}

Akulov, M. (2012). Charisma and the politics of proximity: Case of Nestor Makhno. Conference paper presented at ASN, New York, April 2012.

Arshinov, P. (1995). Istoriia makhnovskogo dvizheniia. Zaporozh'e: "Dikoe pole".

Astashov, A. (2014). Russkii front v 1914-nachale 1917 goda. Voennyi opyt $i$ sovremennost (in Russian). Moscow: Noyyi khronograf.

Belash, A.V., \& Belash, V. F. (1993). Dorogi Nestora Makhno. Kiev: RVTs "Proza".

Borodziej, W., \& Górny, M. (2014). Nasza Wojna. Tom 1: Imperia 1912-1916 (in Polish). Warszawa: WAB.

Danilov, V. et al. (ed.). (2006). Nestor Makhno: Krest'ianskoe dvizhenie na Ukraine 1918-1921. Moscow: ROSSPEN.

Entsiklopedicheskii Slovar' Brokgauza i Efrona. (1896). Vol. 19, pp. 94-96. Saint Petersburg.

Fediuk, V. (2010). Bor'ba s “nemetskim zasil'em”. In Rossiia i Germaniia v XX veke (Ed.), Karl Eimermacher, Gennadii Bordiukov et Astrid Volpert (pp. 78-96). Moscow: AIRO-XXI.

Leonhard, J. (2014). Die Buechse der Pandora: Geschichte des Ersten Weltkrieges (in German). Verlag C. H. Beck.

Makhno, N. (1992). Vospominaniia. Moscow: Respublika.

Neufeld, D. (1921). Ein Tagebuch aus dem Reiche des Totentanzes. Emden: Selbstverlag.

Obshchii svod po imperii rezul'tatov razrabotki. (1905). Obshchii svod po imperii rezul'tatov razrabotki dannykh pervoi vseobshchei perepisi naselenia, proizvedennoi 28 Ianvaria 1897 goda (pp. 250, 254). Saint Petersburg.

Patterson, S. D. (2013). The Makhnos of memory: Mennonite and Makhnovist narratives of the civil war in Ukraine, $1917-1921$. Master's Thesis. Winnipeg: University of Manitoba. 
Pervaia vseobshchaia perepis' naseleniia Rossiiskoi Imperii, 1897. (1904). Vol. XLI. Tavricheskaia Guberniia, pp. 98, $100,127$. Saint Petersburg, N. A. Nyrkin.

Rubakin, N. A. (1912). Rossiia v tsyfrakh: strana, narod, sosloviia, klassy. Saint Petersburg: Vestnik Znaniia.

Sanborn, J. (2014). Imperial apocalypse: The Great War and the destruction of the Russian Empire. Oxford, UK: Oxford U Press. Schnell, F. (2012). Raume des Schreckens: Gewalt und Gruppenmilitanz in der Ukraine, 1905-1933. Hamburg: Hamburger Edition HIS Verlagsges.

Venger, N. (2011). "Malorusskii bunt" Nestora Makhno i "nemetskii vopros" v Rossii: sotsial'no-psikhologicheskii analiz eskalatsii konflikta. Naukovy visnyk Mykolaivs'koho natsional 'noho universytetu imeni V.O. Sukhomlyns'koho: Zbirnyk naukovykh prat', 3(30), 201. 